\title{
Correction to: British Neolithic Axehead Distributions and Their Implications
}

\section{Peter Schauer ${ }^{1} \cdot$ Andrew Bevan $^{1} \cdot$ Stephen Shennan $^{1} \cdot$ Kevan Edinborough $^{2}$. Tim Kerig $^{3}$ - Mike Parker Pearson ${ }^{1}$}

Published online: 14 January 2020

(C) Springer Science+Business Media, LLC, part of Springer Nature 2020

\section{Correction to: Journal of Archaeological Method and Theory https://doi.org/10.1007/s10816-019-09438-6}

Due to a typesetting mistake, the images of Figs 2 and 3 were mistakenly switched. The original version has been corrected.

The online version of the original article can be found at https://doi.org/10.1007/s10816-019-09438-6

\section{Stephen Shennan \\ s.shennan@ucl.ac.uk \\ Peter Schauer \\ p.schauer@ucl.ac.uk}

Kevan Edinborough

kevan.edinborough@unimelb.edu.au

Tim Kerig

tim.kerig@uni-leipzig.de

Mike Parker Pearson

m.parker-pearson@ucl.ac.uk

1 UCL Institute of Archaeology, 31-34 Gordon Square, London WC1H 0PY, UK

2 University of Melbourne, Melbourne, Australia

3 Universität Leipzig, Leipzig, Germany 